University of Nebraska - Lincoln

DigitalCommons@University of Nebraska - Lincoln

Educational Psychology Papers and

Publications

Educational Psychology, Department of

2006

\title{
Buddhism and Adolescent Alcohol Use in Thailand
}

Ian Newman

University of Nebraska-Lincoln, inewman1@unl.edu

Duane F. Shell

University of Nebraska-Lincoln, dshell2@unl.edu

Tiandong Li

University of Nebraska-Lincoln

Saranya Innadda

University of Nebraska-Lincoln

Follow this and additional works at: https://digitalcommons.unl.edu/edpsychpapers

Part of the Educational Psychology Commons

Newman, Ian; Shell, Duane F.; Li, Tiandong; and Innadda, Saranya, "Buddhism and Adolescent Alcohol Use in Thailand" (2006). Educational Psychology Papers and Publications. 96.

https://digitalcommons.unl.edu/edpsychpapers/96

This Article is brought to you for free and open access by the Educational Psychology, Department of at DigitalCommons@University of Nebraska - Lincoln. It has been accepted for inclusion in Educational Psychology Papers and Publications by an authorized administrator of DigitalCommons@University of Nebraska - Lincoln. 
Published in Substance Use E Misuse 41 (2006), pp. 1789-1800; doi: 10.1080/10826080601006490

Copyright (C) 2006 Informa Healthcare (Taylor \& Francis). Used by permission.

A brief interpretation of these data was presented as a poster at the 128th Annual Meeting of the American Public Health Association (November 2000), Boston, Massachusetts. and at the XVIIth World Conference on Health Promotion and Health Education (July 2001), Paris.

\title{
Buddhism and Adolescent Alcohol Use in Thailand
}

\author{
Ian M. Newman, Duane F. Shell, Tiandong Li, and Saranya Innadda \\ Nebraska Prevention Center for Alcohol and Drug Abuse, \\ University of Nebraska-Lincoln, Lincoln, NE, USA

\begin{abstract}
Corresponding author - Dr. Ian M. Newman, Director, Nebraska Prevention Center for Alcohol and Drug Abuse, Department of Educational Psychology, University of Nebraska-Lincoln, P.O. Box 880345, Lincoln, NE 68588-0345; e-mail inewman1@unl.edu
\end{abstract}

\begin{abstract}
A sample of 2019 Thai secondary school students in grades equivalent to U.S. 10 through 12 completed a 43-item alcohol expectancy questionnaire in June 2000. Factor analysis revealed four factors: (a) positive expectancies, (b) negative expectancies, (c) sex and power expectancies, and (d) religious expectancies. Practicing Buddhists were less likely to drink than nonpracticing Buddhists and had fewer positive and more negative expectancies about alcohol. Among students who did drink, Buddhist beliefs did not appear to influence whether or not they were binge drinkers. Buddhist beliefs may influence decisions to drink but not decisions related to drinking patterns.
\end{abstract}

Keywords: religion, religiosity, expectancies, alcohol expectancy questionnaire

\section{Introduction}

The current Thai alcohol scene is especially volatile. At the end of 1999 the government privatized liquor production, which it had previously controlled though a system of concessions. Alcohol production and use increased significantly. Today, Thai and foreign brewers vie aggressively for beer market share as multinational liquor companies and wineries vie for their respective markets. With government encouragement, through a program called OTOP (One Tambon [village] One Product), sarto (rice wine) and fruit wine production has increased significantly.

\section{Buddhism}

Buddhism is the prevailing religion of Thailand. About $95 \%$ of all Thai are Buddhist. The country has approximately 18,000 Buddhist temples and 140,000 Buddhist priests. Nearly all Buddhist males in Thailand enter wats (temple monasteries) and serve as Buddhist monks for at least a few days or months during their adolescence. Buddhism teaches its followers five precepts: (a) kill no living being, (b) never take that which is not freely given, (c) avoid sexual misconduct, (d) tell the truth, and (e) refrain from taking intoxi- 
cants. Most scholars interpret the fifth precept as meaning total abstinence from alcohol and illegal drugs, but a few argue that it means avoiding excessive use. Nevertheless, alcohol is widely used and is an important part of many ceremonies and family celebrations. It is an important part of the ordination of young men as monks, an important part of funerals, and is used as an offering in spirit houses. Spirit houses are small replicas of simple temples containing a statue of Buddha and found near the entrance to houses or buildings. Each day devotees provide offerings of fruit, flowers, and occasionally alcohol. In a similar fashion, alcohol is used as an offering by farmers during plowing, planting, and harvesting.

\section{Alcohol Use in Thailand}

There are only limited data describing the present-day alcohol use in Thailand. In 1999 the World Health Organization published estimates of alcohol use indicating that the between 1970 and 1972 and 1994 and 1996 there had been a 333\% increase in per capita consumption among those older than age of 15 (WHO, 1999, p. 13) At about the same time, an expert panel estimated unrecorded in-home production to be approximately $2.0 \mathrm{~L}$ per capita (WHO, 2004, p. 2). A national survey in 2001 indicated 32.7\% of the total population over age 15 consumed alcohol (55.9\% of males and $9.8 \%$ of the females) (WHO, 2004, p. 1). Among youths aged 15 to 19 years old, $19.9 \%$ of males and $1.9 \%$ of females consumed alcohol (WHO, 2004, p. 2). Regional surveys suggest these estimates may be low. A 1999 survey in Chiang Rai reported that $92.5 \%$ of the males aged 15 to 21 and $80.5 \%$ of the females had consumed alcohol in the previous 3 months (WHO, 2004, p. 2). Our own data, gathered in Chonburi Province, indicated that $45.8 \%$ of high school males and $23.0 \%$ of females had consumed alcohol in the previous 12 months. Our data indicate that beer is the most popular form of alcohol for boys (39.0\%), followed by distilled spirits $(31.1 \%)$ and wine $(20.2 \%)$. For girls, $60.6 \%$ of this sample reported drinking wine, $24.9 \%$ beer, and $13.6 \%$ distilled spirits. A small population of the boys, $3.7 \%$, and $0.8 \%$ of the girls reported drinking indigenous forms of alcohol like "yar-dong."

While estimates of alcohol use are limited, there is growing evidence of alcohol's contribution to premature death and disability through automobile crashes. It has been reported that $62 \%$ of traffic crash victims have positive blood alcohol levels, and that $45 \%$ of all traffic crashes involve alcohol (WHO, 2004, p. 4). Forty-four percent of traffic crash injury victims seeking emergency medical services in public hospitals have a blood alcohol concentration of $0.1 \%$ or higher (WHO, 2004, p. 4).

There are overt signs of government concern about the negative effects of alcohol, as seen in attempts to reduce the rate of drunk driving casualties, especially at high-risk times such as Songkran (Thai New Year), and in attempts to reduce alcohol sales by restricting television advertising to nighttime hours, by restricting the sale of alcohol in certain eating establishments, and by reducing the open hours for entertainment sites. Officially, Thailand prohibits the purchase of alcohol by persons under 18, but law enforcement has been inconsistent.

\section{Religion and Alcohol Use}

Relationships between religion and alcohol use and attitudes toward alcohol have been recognized for some time (Skolnick, 1958; Schlegal and Sanborn, 1979; Perkins, 1985; Patock-Peckham, Hutchinson, Cheong, and Nagoshi, 1988; Francis and Mullen, 1993). A range of studies suggested that religion, measured in a variety of ways, moderates alco- 
hol use. The effects of religion, however, were not consistent across all studies. Schlegal and Sanborn (1979) noted differences between Protestants and Catholics, and Zucher and Hartford (1983) found differences between college students and adults. Hilton and Clark (1987) noted that denominational differences in drinking rates among Christians weakened over time. Poulson, Eppler, Satterwhite, Wuensch, and Bass (1998), reporting on college students, noted a strong relationship between religious belief and quantity of alcohol consumed among women but not among men. Koopmans, Slutske, Baal, and Boomsma (1999) found similar results among Dutch adolescents. Isralowitz and Ong (1990), studying Chinese undergraduate college students in Singapore, reported that religious values were not a significant factor in students' alcohol use.

Miller (1998) concluded that religious involvement may be an important "protective factor" against alcohol misuse. Others concurred with Miller's conclusion (Hawkins, Catalano, and Miller 1992; Cochran, 1992; Forthun, Bell, Peek, and Sun, 1999). Miller noted, however, that research in this area has not been especially explicit in differentiating between spirituality, which he suggested is understood at the level of the individual, and religion, which he described as a social phenomenon with an organized structure of rituals and practices that can be observed. Some make further distinctions as between religion (membership in a group) and religiosity (activities and practices).

How religion, however defined, affects alcohol consumption is not well understood. Whether religion's effect is due to a principled abstinence from alcohol use, to the presence of social support for abstinence or moderation, or to its time-occupying nature that competes with opportunities for alcohol use is a question that remains largely unexplored. The interplay of family and religion may create an important posited protective factor (Mason and Windle, 2001). Research suggested, for example, that supportive and emotionally close families are often associated with both religion and low risk alcohol use (Jessor and Jessor, 1997). Families may influence peer selection (Burkett and Warren, 1987) and educational aspirations (Ellickson and Hays, 1992), both of which are associated with lower alcohol use. Mason and Windle (2001) suggest that religion is an important mediator between family, social support, and adolescent use. In general, religious belief appears to moderate use but there is little agreement as to the degree or the dynamics of this effect.

\section{Method}

\section{Instrument Development}

The work of Smith and Goldman (1995) served as a guide for the Thai alcohol expectancy scale development. A series of 20 personal interviews and focus groups involving 80 students in groups of 6-9 were conducted in 1999 with Thai high school students to elicit alcohol related expectancies. All interviews and focus groups were led by the Thai member of our research group. The alcohol expectancies identified were so similar to those of Brown, Christiansen, and Goldman's (1987) Adolescent Alcohol Expectancy Questionnaire that it was decided to translate that questionnaire into Thai. For the translation, the shorter, revised AEQ (George et al., 1995), consisting of 40 items, was used. Alcohol expectancies related to Buddhism, which were described by interviewees and focus group members, all related to Buddhism's fifth precept, which prohibits drinking alcohol. Three alcohol expectancy statements about sin, abstinence, and wrong practices were added to the questionnaire, bringing the total number of expectancy items to 43. Expectancy items 
were rated on a six-point Likert scale from 1 (strongly agree) to 6 (strongly disagree). In addition, 25 questions asked about alcohol use and demographic characteristics. The first draft of the questionnaire was reviewed by 10 students who suggested some changes. One hundred secondary school students then pretested the draft questionnaire. Minor revisions to the wording of instructions and some items followed. The final version of the Thai questionnaire was back-translated into English to verify meaning.

\section{Sample}

The questionnaire was completed in June 2000 by 2064 students from secondary schools in three cities in Chonburi Province. Each city had one major high school. Schools were selected to approximate the population of the area. One school was located in a coastal trade, transportation and administration center, where the main industry is tourism. The second school was located in a trade and transportation center that served mainly the surrounding military community. The third school was located in a trade and transportation center for a mostly rural area. The sample is described further in Table 1.

Classes from each school were randomly selected in proportion to the total student population. Teachers were provided special training on the data collection and how to maintain confidentiality and anonymity. Questionnaires were administered in accordance with local procedures. All questionnaires were anonymous. Students completing the questionnaire were told the information collected would assist in the improvement

Table 1. Selected demographic characteristics of the sample

\begin{tabular}{|c|c|c|c|c|c|c|}
\hline & \multicolumn{2}{|c|}{ Males } & \multicolumn{2}{|c|}{ Females } & \multicolumn{2}{|c|}{ Total } \\
\hline & $\mathrm{N}$ & $\%$ & $\mathrm{~N}$ & $\%$ & $\mathrm{~N}$ & $\%$ \\
\hline Age & 827 & 41.0 & 1,192 & 59.0 & 2,019 & 100.0 \\
\hline 15 yrs or younger & 267 & 32.3 & 377 & 31.6 & 644 & 31.9 \\
\hline 16-17 years old & 432 & 52.2 & 683 & 57.3 & 1,115 & 55.2 \\
\hline 18 and older & 128 & 15.5 & 132 & 11.1 & 260 & 12.9 \\
\hline Totals & 827 & 100.0 & 1,192 & 100.0 & 2,019 & 100.0 \\
\hline \multicolumn{7}{|l|}{ Grade } \\
\hline 10 & 415 & 50.3 & 502 & 42.1 & 917 & 45.5 \\
\hline 11 & 250 & 30.3 & 448 & 37.6 & 698 & 34.6 \\
\hline 12 & 160 & 19.4 & 241 & 20.2 & 401 & 19.9 \\
\hline Totals & 825 & 100.0 & 1,191 & 100.0 & 2,016 & 100.0 \\
\hline \multicolumn{7}{|l|}{ Religion } \\
\hline Buddhist & 806 & 97.5 & 1,154 & 96.8 & 1,960 & 97.1 \\
\hline Other & 21 & 2.5 & 38 & 3.2 & 59 & 2.9 \\
\hline Totals & 827 & 100.0 & 1,192 & 100.0 & 2,019 & 100.0 \\
\hline \multicolumn{7}{|l|}{ School location } \\
\hline Military base & 472 & 57.1 & 545 & 45.7 & 1,017 & 50.4 \\
\hline Rural area & 188 & 22.7 & 365 & 30.6 & 553 & 27.4 \\
\hline Tourist city & 167 & 20.2 & 282 & 23.7 & 449 & 22.2 \\
\hline Totals & 827 & 100.0 & 1,192 & 100.0 & 2,019 & 100.0 \\
\hline
\end{tabular}


of school-based alcohol education programs. Students also were told that analysis would aggregate the data and no individual or classroom specific data would be available. Further confidentiality was provided through seating arrangements. All students in the sampled classes completed the questionnaire in accordance to local policy. Written parental consent was waived by the IRB. It was not a policy in the participating schools to seek parental consent before students completed anonymous questionnaires of this type. All answer sheets were sealed in envelopes when completed. The sealed envelopes were collected by a member of our research group. Two thousand and sixty four questionnaires were collected, of which 2019 (97\%) were usable.

\section{Analysis}

Factor analysis identified the dimensionality of the expectancy items. The initial factor analysis was done on the entire 43-item scale. Preliminary selection of factors was done using eigenvalues and analysis of the scree plot of eigenvalues. Both of these analyses indicated the number of potential factors to be between three and seven. To determine the best factor structure, analyses were conducted extracting three through seven factors using both Varimax and Promax rotations. The results were compared for quality of the factors solution and conceptual soundness.

As a result, a four-factor structure was identified as the most adequate. The four-factor solution produced relatively clean factors, with few cross-loadings of items on multiple factors and a conceptually coherent solution. Following the initial determination of the best factor structure, the factors were cleaned by removing ill-fitting items and items with high cross-loadings on multiple factors. This resulted in the removal of 9 items, producing an instrument of 34 items. The final factor solution using principal components with Varimax rotation produced four factors: (a) positive expectancies, (b) negative expectancies, (c) sex and power expectancies, and (d) religious expectancies. Coefficient alpha reliability estimates for the four factors were $.91, .83, .68$, and .81 , respectively.

Alcohol use and alcohol expectancies were compared for students who were defined as "practicing" (40.4\%) and "nonpracticing" (59.6\%) Buddhists. Defining Buddhism was problematic. Students were categorized as "practicing Buddhism" if they answered yes to the question, "Are you currently practicing your religion?" and if they indicated they attended temple ceremonies, even if not regularly. Unlike some Western religions, Thai Buddhists do not have a weekly ritual of temple attendance that would indicate devotion. Temple attendance did create a meaningful class of students for this analysis.

\section{Results}

\section{Buddhist Practice and Drinking Behavior}

Students who were classified as practicing Buddhists, as defined for this study, were less likely to drink than students who did not practice Buddhism. Significantly fewer practicing Buddhists (28\%) than non-practicing Buddhists (35\%) reported drinking within the past year (Table 2). Table 2 also shows that among students who drank, there were no significant differences between practicing and non-practicing Buddhists in binge drinking (drinking five or more drinks at one sitting in the last 30 days) or more frequent drinking (drinking one or more times within the last 30 days). 
Table 2. Buddhist practice and drinking behavior

\begin{tabular}{|c|c|c|c|c|c|c|}
\hline & \multicolumn{2}{|c|}{ Practicing } & \multicolumn{2}{|c|}{ Non-practicing } & \multirow[b]{2}{*}{ Total } & \multirow[b]{2}{*}{$x^{2}$} \\
\hline & $\mathrm{N}$ & $\%$ & $\mathrm{~N}$ & $\%$ & & \\
\hline \multicolumn{7}{|l|}{ All students } \\
\hline Drank in last year & 218 & 28 & 402 & 35 & 620 & $10.38^{* * *}$ \\
\hline Did not drink last year & 572 & 72 & 763 & 65 & 1335 & \\
\hline Totals & 790 & 100 & 1165 & 100 & 1955 & \\
\hline \multicolumn{7}{|l|}{ Students who drink } \\
\hline Binged in last 30 days & 51 & 23 & 116 & 29 & 167 & 2.14 \\
\hline Did not binge in last 30 days & 167 & 77 & 286 & 71 & 453 & \\
\hline Totals & 218 & 100 & 402 & 100 & 620 & \\
\hline \multicolumn{7}{|l|}{ Students who drink } \\
\hline Drank in last 30 days & 100 & 46 & 200 & 50 & 300 & .91 \\
\hline Did not drink in last 30 days & 118 & 54 & 201 & 50 & 319 & \\
\hline Totals & 218 & 100 & 401 & 100 & 619 & \\
\hline
\end{tabular}

${ }^{*} \mathrm{p}<.05 ; * * \mathrm{p}<.01 ; * * * \mathrm{p}<.001$

\section{Buddhist Practice and Alcohol Expectancies}

Students who were practicing Buddhists had different expectancies about alcohol's effects than students who did not practice. Practicing Buddhists had significantly fewer positive and significantly more negative expectancies about alcohol's effects than non-practicing Buddhists. Practicing Buddhists were also significantly more likely to express the expectancy that their religion viewed drinking negatively. Practicing and non-practicing Buddhists did not differ in their expectancies that alcohol could enhance sexual performance and power (Table 3). Although practicing and non-practicing students differed in their expectancies, effect sizes (Table 3) indicated generally small effects. These effects were, however, statistically significant, suggesting they were likely not due to chance.

Table 3. Buddhist practice and expectancies about alcohol's effects

\begin{tabular}{|c|c|c|c|c|c|c|c|}
\hline & \multirow[b]{2}{*}{$\mathrm{df}$} & \multicolumn{2}{|c|}{ Practicing } & \multicolumn{2}{|c|}{ Non-Practicing } & \multirow[b]{2}{*}{$\mathrm{t}$} & \multirow[b]{2}{*}{$\mathrm{d}$} \\
\hline & & M & $\mathrm{SD}$ & $\mathrm{M}$ & SD & & \\
\hline Positive alcohol expectancies & 2009 & 2.97 & .99 & 3.85 & .98 & $2.63^{* *}$ & .12 \\
\hline Negative alcohol expectancies & 2009 & 2.81 & 1.00 & 2.90 & .97 & $-2.08^{*}$ & .09 \\
\hline Sex/power alcohol expectancies & 2009 & 4.78 & 1.00 & 4.73 & 1.00 & 1.21 & .05 \\
\hline Religious alcohol expectancies & 1975 & 2.29 & 1.30 & 2.52 & 1.33 & $-3.90^{* * *}$ & .18 \\
\hline
\end{tabular}

$\mathrm{d}=$ effect size computed by Cohen's $d$. For positive, negative and sex/power expectancies, practicing $n=944$ and not practicing $n=1189$; for religious expectancies, practicing $n=814$ and not practicing $n=1163$.

${ }^{*} \mathrm{p}<.05 ;{ }^{* *} \mathrm{p}<.01 ; * * * \mathrm{p}<.001$ 
Table 4. Drinking behavior and expectancies about alcohol's effects

\begin{tabular}{|c|c|c|c|c|c|c|c|}
\hline & \multirow[b]{2}{*}{ df } & \multicolumn{2}{|c|}{ Drinker } & \multicolumn{2}{|c|}{ Non-drinker } & \multirow[b]{2}{*}{$\mathrm{t}$} & \multirow[b]{2}{*}{$\mathrm{d}$} \\
\hline & & M & SD & M & SD & & \\
\hline Positive alcohol expectancies & 1469.9 & 3.33 & 0.86 & 4.14 & 0.94 & $-19.78^{* * *}$ & .82 \\
\hline Negative alcohol expectancies & 1514.2 & 3.12 & 0.88 & 2.73 & 0.99 & $9.20 * * *$ & .40 \\
\hline Sex/power alcohol expectancies & 1299.4 & 4.61 & 1.03 & 4.81 & 0.98 & $-4.19^{* * *}$ & .20 \\
\hline Religious alcohol expectancies & 1283.8 & 2.78 & 1.35 & 2.27 & 1.29 & $8.23^{* * *}$ & .39 \\
\hline
\end{tabular}

Drinker $=$ drank alcohol in the last year; Non-Drinker $=$ did not drink alcohol in the last year. $\mathrm{d}=$ effect size computed by Cohen's d. For Positive, Negative and Sex/Power expectancies, drinker $n$ $=688$ and non-drinker $n=1414$; for religious expectancies, drinker $n=675$ and non-drinker $n=$ 1389.

${ }^{*} \mathrm{p}<.05 ; * * \mathrm{p}<.01 ; * * * \mathrm{p}<.001$

\section{Differences in Alcohol Expectancies between Drinkers and Non-Drinkers}

Table 4 suggests that students who drank had significantly more positive and less negative expectancies about alcohol's effects than non-drinkers. Drinkers had a greater expectancy that drinking could enhance sexual performance and power. Non-drinkers were significantly more likely to express the expectancy that their religion viewed drinking negatively. There was a large effect size for positive expectancies, suggesting that drinkers expect to have considerably more positive effects from their drinking than do non-drinkers. Effect sizes for negative expectancies and religious expectancies were in the moderate range but suggested meaningful difference between drinkers and non-drinkers. The effect size for sex and power was two tenths of a standard deviation, suggesting a small but potentially meaningful difference.

\section{Differences in Alcohol Expectancies between Bingers and Non-Bingers and Frequency of Drinking}

Among students who drank, there were significant differences in expectancies between students who reported binge drinking (drinking five or more drinks at one sitting) and those who did not binge and between more frequent drinkers (drinking one or more times within the last 30 days) and less frequent drinkers. Tables 5 and 6 show that students who binged and students who drank more frequently had significantly more positive expectancies and higher sex and power expectancies about alcohol than non-bingers and less frequent drinkers. Non-binge drinking and less frequent drinking students were significantly more likely to express the expectancy that their religion viewed drinking negatively. There were no differences in general negative expectancies. There was a large effect sizes for positive expectancies suggesting that bingers and more frequent drinkers expect to have considerably more positive effects from their drinking than do non-bingers and less frequent drinkers. The effect sizes for sex and power and religious expectancies were in the moderate range.

\section{Discussion}

Students' religious practices appear to influence their drinking and their expectancies about alcohol. Students who reported being practicing Buddhists were less likely to drink 
Table 5. Binge drinking and expectancies about alcohol's effects

\begin{tabular}{|c|c|c|c|c|c|c|c|}
\hline & \multirow[b]{2}{*}{$\mathrm{df}$} & \multicolumn{2}{|c|}{ Binger } & \multicolumn{2}{|c|}{ Non-Binger } & \multirow[b]{2}{*}{$\mathrm{t}$} & \multirow[b]{2}{*}{ d } \\
\hline & & $\mathrm{M}$ & SD & $\mathrm{M}$ & SD & & \\
\hline Positive alcohol expectancies & 686 & 3.00 & 0.84 & 3.45 & 0.84 & $-6.27^{* * *}$ & .52 \\
\hline Negative alcohol expectancies & 686 & 3.10 & 0.83 & 3.13 & 0.90 & 0.42 & .04 \\
\hline Sex/power alcohol expectancies & 294.4 & 4.20 & 1.10 & 4.76 & 0.96 & $-6.17^{* * *}$ & .55 \\
\hline Religious alcohol expectancies & 302.1 & 3.15 & 1.41 & 2.64 & 1.29 & $4.27^{* * *}$ & .38 \\
\hline
\end{tabular}

$\mathrm{d}=$ effect size computed by Cohen's d. For positive, negative, and sex/power expectancies, binger $n$ $=186$ and non-binger $n=502$; for religious expectancies, binger $n=183$ and non-binger $n=492$.

${ }^{*} \mathrm{p}<.05 ; * * \mathrm{p}<.01 ; * * * \mathrm{p}<.001$

than students who were non-practicing. Practicing Buddhists expected more negative and less positive outcomes from drinking than non-practicing Buddhists, and expressed a greater belief that their religion viewed drinking negatively. These findings suggest that students' religious beliefs do influence both what outcomes they expect from drinking and their decision to drink or not.

Among students who did drink, however, religious practice had no effect on whether students binge drank or on the frequency of drinking. This suggests that while religious practices may influence the decision to drink or not, it does not appear to influence drinking styles once the decision to drink is made.

Students who did not drink were more likely to endorse the belief that their religion viewed drinking negatively. Among students who drank, regardless of whether they were practicing or non-practicing Buddhists, those who did not binge or did not drink frequently were also more likely to endorse the belief that their religion viewed drinking negatively. This suggests that those who felt that their religion has negative views of drinking were less likely to drink or if they did drink, were more likely to drink responsibly regardless of whether they regularly practiced their religion.

Table 6. Frequency of drinking and expectancies about alcohol's effects

\begin{tabular}{|c|c|c|c|c|c|c|c|}
\hline & \multirow[b]{2}{*}{ df } & \multicolumn{2}{|c|}{$\begin{array}{c}\text { Drank in last } \\
30 \text { days }\end{array}$} & \multicolumn{2}{|c|}{$\begin{array}{l}\text { Did not drink } \\
\text { in last } 30 \text { days }\end{array}$} & \multirow[b]{2}{*}{$\mathrm{t}$} & \multirow[b]{2}{*}{ d } \\
\hline & & M & SD & M & SD & & \\
\hline Positive alcohol expectancies & 685.0 & 3.12 & 0.85 & 3.53 & 0.82 & $-6.50^{* * *}$ & .48 \\
\hline Negative alcohol expectancies & 685.0 & 3.10 & 0.83 & 3.14 & 0.92 & .55 & .04 \\
\hline Sex/power alcohol expectancies & 652.2 & 4.39 & 1.09 & 4.82 & 0.93 & $-5.51^{* * *}$ & .41 \\
\hline Religious alcohol expectancies & 652.8 & 3.01 & 1.40 & 2.56 & 1.26 & $4.33^{\star * *}$ & .33 \\
\hline
\end{tabular}


The effects of religious beliefs were not large. The majority of students did not drink, regardless of their religious practices. Although the effects of religious practices were not large, they may still be important. Even a small influence may make a meaningful difference in students' beliefs about drinking and drinking behaviors.

This is the first known study of expectancies about alcohol's effects and religious practice in Thailand. The results of most first studies may not be immediately generalizable to the larger population, but they are often important in initiating dialogue about important topics.

\section{Study's Limitations}

The sample for this study represented only one of Thailand's provinces. The questionnaire had not been used before. The number of questions asking about religion linked expectancies was limited. The questions defining Buddhist practice explored only a narrow slice of devotion to the faith. Nevertheless, the results suggest that Buddhist practice may be related to alcohol use among Thai adolescents. Because Buddhism is so common in Thailand and because one of Buddhism's important teachings, the fifth precept, speaks against the use of alcohol it would seem important to understand more clearly how Buddhism might affect alcohol use and other risky behaviors among adolescents.

\section{Future Needed Research}

It would be useful to repeat this study in a different part of the country to confirm the suggested significance of Buddhism and expectancies about alcohol's effects. In addition to replication, it would be useful to seek a better understanding of how young people interpret Buddhist teachings about alcohol by conducting a series of interviews and focus groups with young people specifically exploring how Buddhism might affect alcohol use. A first result of qualitative work of this sort would be a wider range of alcohol expectancy questions linked to Buddhism. A second result would be a more sophisticated measure of devotion to Buddhist practice, allowing for a better definition of students classified as practicing their religion faithfully and those practicing less faithfully. The interviews and focus group discussions that preceded the study suggested that the AAEQ was an adequate instrument. It certainly presented useful data. However, another round of open ended interviews and focus group discussions could yield potentially useful expectancies more sensitive to local practices and cultural values. Religions are important components in all cultures and their potential influence on health, especially among young people, is rarely explored. This study suggests a need to consider religion as an important factor in a wide range of health behaviors.

\section{Acknowledgement}

The authors acknowledge with appreciation the assistance provided by Khalid Almutairi and Michelle Maas.

\section{Résumé}

\section{Bouddhisme et utilisation d'alcool d'adolescent en Thaïlande}

Un échantillon de 2019 lycéens Thaïlandais au niveau équivalent aux classes 10 à 12 aux États-Unis a rempli un questionnaire à 42 questions sur l'attente de l'emploi de l'alcool. 
L'analyse des facteurs a mis à jour quatre facteurs: 1) les attentes positives 2) les attentes négatives 3) les attentes qui se rapportent au sexe et au pouvoir 4) les attentes religieuses. Les bouddhistes pratiquants ont eu moins d'attentes positives et plus d'attentes négatives quant à l'alcool. Entre les étudiants qui ont vraiment bu, la foi bouddhiste n'a pas apparu à avoir un influence quant à s'ils vont faire la noce où non. La croyance en bouddhisme peut exercer une influence sur la décision à boire où à ne pas boire, mais pas sur les décisions ayant rapport à la mode de comportement quand ils buvent.

\section{Resumen}

\section{Buddhism y uso del alcohol del adolescente en Tailandia}

Una muestra de 2019 estudiantes de secundaria en Tailandia en niveles equivalentes de 10 a 12 en los Estados Unidos completaron un cuestionario de 43 preguntas con respecto a la expectativa de alcohol. El factor an'alisis reveló cuatro factores: 1) expectativas positivas, 2) expectativas negativas, 3) expectativas de sexo y poder expectativas religiosas. En los budistas practicantes era menos probable que bebieran que los no-practicantes y tenían menos expectativas positivas y más negativas a cerca del alcohol. Entre los estudiantes que bebían, las creencias budistas no parecían influenciar en si eran o no bebedores masivos. Las creencias budistas pueden influenciar en la decisión de beber, pero no en decisiones relacinadas con patrones de bebida.

\section{The Authors}

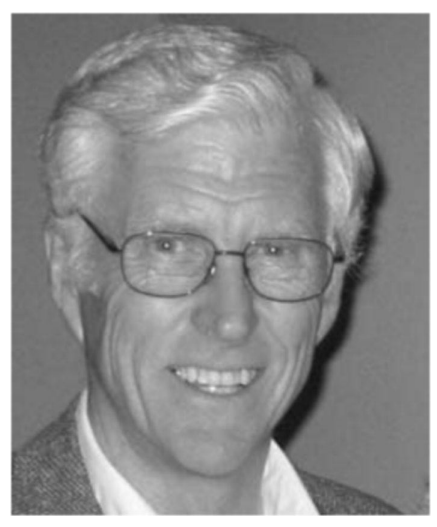

Ian M. Newman, Ph.D., is the Wesley C. Meierhenry Distinguished Professor, Department of Educational Psychology, College of Education and Human Sciences, University of Nebraska-Lincoln. His research focuses on prevention of adolescent health-risk behaviors.

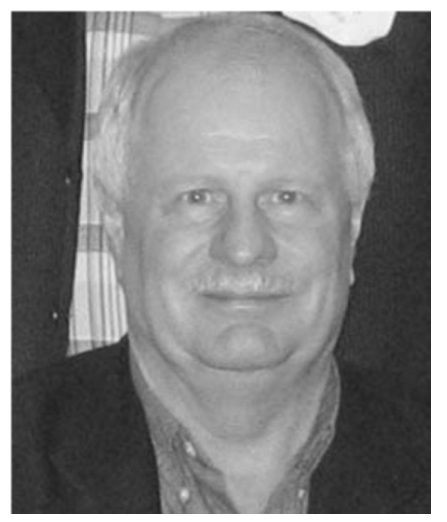

Duane F. Shell, Ph.D., is research associate professor in the Department of Educational Psychology, College of Education and Human Sciences, at the University of Nebraska-Lincoln. His research focuses on psychological constructs that predict learning and behaviors in school children. 

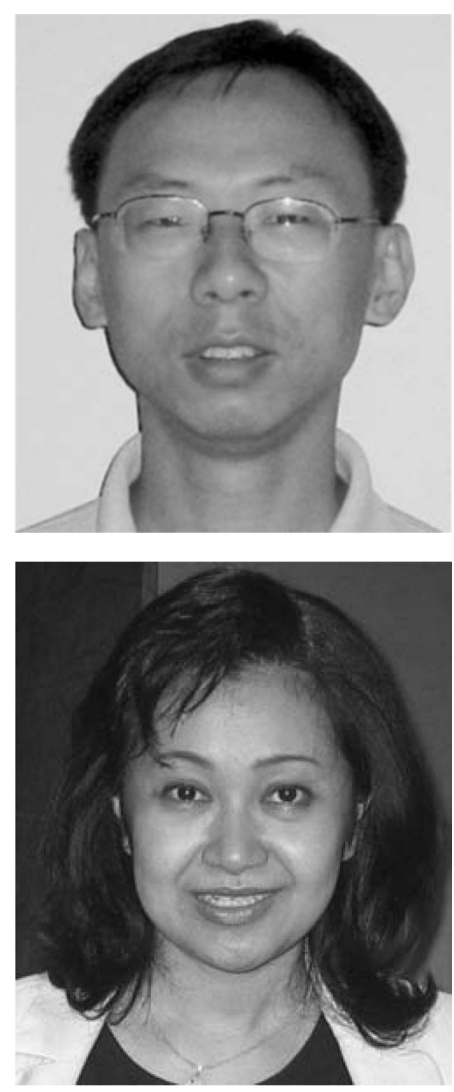

Tiandong Li, MS, studied survey design and statistics at the Gallup Research Center at the University of Nebraska-Lincoln. He is currently a statistician at Westat in Rockville, Maryland.
Saranya Innadda, Ph.D., received her doctorate in health education in 2002 from the University of Nebraska-Lincoln. The design of an alcohol expectancy scale for Thai adolescents was the focus of her dissertation research. She currently is the vice-president of research and development for Papanan Limited in Bangkok.

\section{Glossary}

Alcohol related expectancies: An individual's associations between alcohol use and specific outcomes of alcohol use (Smith and Goldman, 1995).

Spirituality: An individual characteristic consisting of personal beliefs and practices at the level of the individual (Miller, 1998).

Religion: A social phenomenon with an organized set of beliefs and rituals that encode attitudes toward and understanding of the essence or nature of reality (Reese, 1996, p. 647; Miller, 1998).

Adjective: Religious

Religiosity, Religiousness, Religious practice: The extent to which the individual is faithful to or complies with the organized structure of rituals and teachings (Miller, 1998).

\section{References}

Brown, S. A., Christiansen, B. A., Goldman, M. S. (1987). The Alcohol Expectancy Questionnaire: An instrument for the assessment of adolescent and adult alcohol expectancies. Journal of Studies on Alcohol 48(5):483-491.

Burkett, S. R., Warren, B. O. (1987). Religiosity, peer associations, and adolescent marijuana use: A panel study of underlying causal structures. Criminology 25:109-131. 
Cochran, J. K. (1992). The effects of religiosity on adolescent self-reported frequency of drug and alcohol use. Journal of Drug Issues 22:91-104. 1800 Newman et al.

Ellickson, P. L., Hays, R. D. (1992). On becoming involved with drugs: Modeling adolescent drug use over time. Health Psychology 11(6):377-385.

Forthun, L. F., Bell, N. J., Peek, C. W., Sun, S.-W. (1999). Religiosity, sensation seeking, and alcohol/ drug use in denominational and gender contexts. Journal of Drug Issues 29:75-90.

Francis, L. J., Mullen, K. (1993). Religiosity and attitude toward drug use among 13-15 year olds in England. Addiction 88(5):665-672.

George, W. H., Frone, M. R., Cooper, M. L., Russell, M., Skinner, J. B., Windle, M. (1995). A revised Alcohol Expectancy Questionnaire: Factor structure confirmation and invariance in a general population sample. Journal of Studies on Alcohol 56:177-185.

Hawkins, J. D., Catalano, R. F., Miller, J. Y. (1992). Risk and protective factors for alcohol and other drug problems in adolescence and early adulthood: Implications for substance abuse prevention. Psychological Bulletin 112(1):64-105.

Hilton, M. E., Clark, W. B. (1987). Changes in American drinking patterns and problems 1967-1984. Journal of Studies on Alcohol 48:515-522.

Isralowitz, R. E., Ong, T.-H. (1990). Religious values and beliefs and place of residence as predictors of alcohol use among Chinese college students in Singapore. International Journal of the Addictions 25(5):515-529.

Jessor, R., Jessor, S. L. (1997). Problem behavior and psychological development: A longitudinal study of youth. San Diego, CA: Academic Press.

Koopmans, J. R., Slutske, W. S., van Baal, G. C., Boomsma, D. I. (1999). The influence of religion on alcohol use initiation: Evidence of genotype $\mathrm{X}$ environmental interaction. Behavior Genetics 29(6):445-453.

Mason, W. A., Windle, M. (2001). Family, religion, school, and peer influences on adolescent alcohol use: A longitudinal study. Journal of Studies on Alcohol 62:44-53.

Miller, R. V. (1998). Researching the spiritual dimensions of alcohol and other drug problems. Addiction 93(7):979-990.

Patock-Peckham, J. A., Hutchinson, G. T., Cheong, J., Nagoshi, C. T. (1988). Effect of religion and religiosity on alcohol use in a college student sample. Drug and Alcohol Dependence 49:81-88.

Perkins, H. W. (1985). Religious traditions, parents and peers as determinants of alcohol and drug use among college students. Review of Religious Research 27:15-31.

Poulson, R. L., Eppler, M. A., Satterwhite, T. N., Wuensch, K. L., Bass, L. A. (1998). Alcohol consumption, strength of religious beliefs, and risky sexual behavior in college students. Journal of American College Health 46(5):227-232.

Reese, W. L. (1996). Dictionary of philosophy and religion: Eastern and Western thought. Atlantic Highlands, NJ: Humanities Press.

Schlegal, R. P. Sanborn, M. D. (1979). Religious affiliation and adolescent drinking. Journal of Studies on Alcohol 40:693-703.

Skolnick, J. H. (1958). Religious affiliation and drinking behavior. Journal of Studies on Alcohol 19:452-470.

Smith, G. T., Goldman, M. S. (1995). Alcohol expectancy theory and the identification of high-risk adolescents. In: Boyd, G. M., Howard, J., Zucker, R. A., eds. Alcohol Problems among adolescents: Current directions in prevention research. Hillsdale, NJ: Lawrence Erlbaum, pp. 86- 104.

World Health Organization. (1999). Global status report on alcohol (Document \#WHO/HSC/SAB/ 99.11). Geneva: WHO.

World Health Organization. (2004). Global status report on alcohol 2004: Country profiles: Thailand. Retrieved from http://www.who.int/substance_abuse/publications/alcoholpolicycountryprofilessearo/en/

Zucher, R. A., Hartford, T. C. (1983). National study of the demographics of adolescent drinking practices in 1980. Journal of Studies on Alcohol 44:974-985. 